\title{
On Alcyonium pulmonis instar lobatum Ellis.
}

\author{
By
}

\section{R. Hartmeyer, Berlin.}

With one Figure in the Text.

In the year 1755 Ellis described in his "Natural History of the Corallines," as "Alcyonium pulmonis instar lobatum," a "sea production" from Whitstable, which the fishermen there had brought to him under the name of "Sea-Fig." As regards the systematic position of this form, he expresses himself only in so far as to place it with the Alcyonians, a group in which were united at that time, along with true species of Alcyonium, Ascidians, Hydroids, Sponges and even Algæ. As a doubtful synonym of his species Ellis put forward the Pulmo marinus of Rondelet (1555), which however has nothing whatever to do with it and indeed cannot be certainly determined. During the following years, Ellis' work was translated into several languages. A Dutch and a French translation, both dating from the year 1756, are known to me, the former by Tak, the latter by Allamand. There is also a German translation by Krüniz dated 1767 .

Before I proceed with the history of this species it appears to me advisable first of all to define it, so as to be able in the further course of the discussion to deal with a fixed systematic conception. The description and the figures which Ellis gives are so characteristic that the "Alcyonium pulmonis instar lobatum" can only be identified as a compound Ascidian. As such the species was recognised, as soon as ever the close relationship of the colony-forming ascidians, which had previously been regarded as Alcyonians, to the simple ascidians was determined, that is to say about the year 1816. It is remarkable however that the form has never since been the subject of a thorough description, although it is mentioned in many textbooks and handbooks, as well as in faunistic papers, during the following 30 or 40 years. In more recent literature the species receives scanty mention, mostly only as a list name or as an uncertain species, whilst it has practically entirely disappeared from the most modern literature.

My wish to clear up if possible once for all this form by the examination of typical local examples has now been carried out through 
the kindness of Dr. Allen. I received three colonies sent by him, which had been collected by fishermen at West Mersea, Essex, that is to say in a locality which from a faunistic standpoint can hardly be different from the neighbourhood of Whitstable. Especially valuable to me was however the accompanying information that the name "Sea-Fig" has been retained there down to the present day. We have therefore every right to suppose that these specimens from West Mersea are the same species as the "Alcyonium pulmonis instar lobatum" of Ellis.

An examination of these three colonies has yielded a result which I had previously anticipated: Ellis' species is no other than the wellestablished Macroclinum pomum (Sars), which is frequently mentioned in the most recent literature and is everywhere common in the North

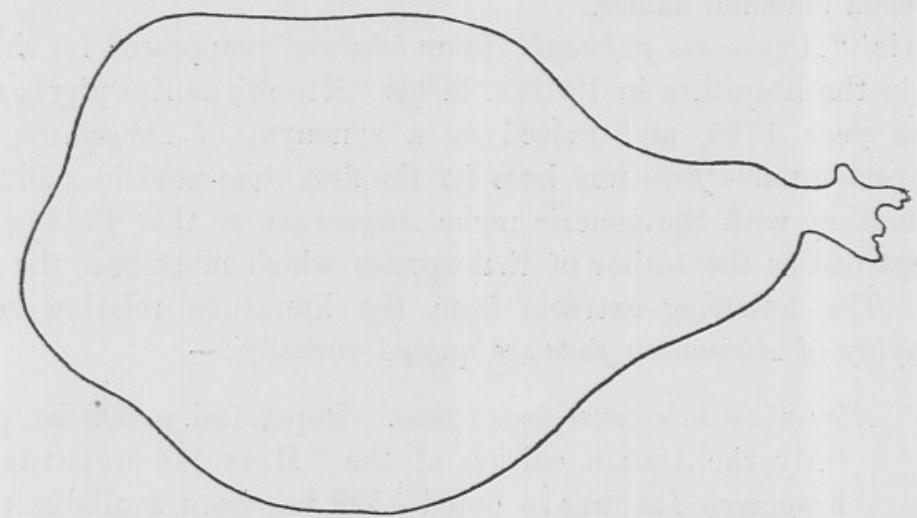

Fig. 1.-Macroclinum pulmonaria (Ell. Sol.). Colony from West Mersea. Natural size.

Sea. This supposition must have already forced itself upon the mind of anyone acquainted with the species, when reading Ellis' description, a model of its kind, and comparing it with his figures. After the direct proof of the occurrence of Macroclinum pomum on the Essex coast no further doubt of the identity of the two forms would seem to be possible.

Of the three colonies before me from West M ersea, the largest has a typical fig-like shape. The anterior end is broadened, the posterior end is tapered and runs out into a quite short, stem-like process, which serves for its attachment. The colony is strongly compressed laterally. Its length is $7.9 \mathrm{~cm}$., its greatest breadth $5.1 \mathrm{~cm}$., whilst its thickness never exceeds $1 \cdot 1 \mathrm{~cm}$. The colour is greenish grey. The systems are not very clearly recognisable, but are undoubtedly present. The whole habitus of the colony with the separate individuals shining through like yellow seeds, is very aptly characterised by the descrip- 
tion "Sea-Fig." A second colony is considerably smaller. The length is ouly $3.4 \mathrm{~cm}$, the breadth $2.7 \mathrm{~cm}$. The posterior end is less strongly tapered, the remaining characters are on the other hand the same. Finally the third colony forms only a small cushion on a sponge.

So much as to the material in hand and the identity of Ellis' form with the Macroclinum pomum of recent literature. In order to establish the synonomy and the correct specific name I will now proceed to the history of the species, which is specially complicated by the fact that in the old literature for many decades the species was confused with a sponge, which to-day in sponge-nomenclature bears the name Ficulina ficus (Pall.). Ellis and Solander (1786) first pointed out this error, and Esper (1806) also recognised it, but Lamarck (1815) was the first and after him Lamouroux (1816) to distinguish the two species by special binomial names.

Ellis' "Alcyonium pulmonis instar lobatum" reappeared for the first time in the literature in Pallas, in his "Elenchus Zoophytorum" of the year 1766, and indeed as a synonym of Alcyonium ficus. The specific name ficus was here for the first time used in a binomial combination with the generic name Alcyonium, so that Pallas must be regarded as the author of that species which must bear the name ficus. The following extracts from the literature relating to the synonymy of Alcyonium ficus are quoted verbally:-

(1) Alcyonium tuberosum forma ficus. Imper. ital. p. 599 lat. p. 839. Only the Italian edition of the "Historia naturale" of Francesco Imperato dated 1599 has been available to me. A form is there described and figured on p. 734, under the name "Alcyonio tuberoso in forma di fico frutto: Alcyonio quinto di Dioscoride," which is without doubt a sponge and has been identified by the spongiologists as Ficulina ficus. I do not know whether the page reference given in the Italian edition, namely page 599 in Pallas, is due to an error, or whether it refers to some other edition. A date of publication for Pallas is not given. Moreover the same page reference is found in Esper. In the latter's work the quotation from Imperato (Esper writes Imperati) reads: "Alcyonium tuberosum forma Ficus: Halcyoneum quintum Dioscoridis." I will take this opportunity of mentioning that the "Alcyonio quinto di Dioscoride" quoted from Imperato is mentioned in his Materia medica of the year 1478 as "Alcyonii quinta species." A determination of this form is hardly possible. 
(2) Alcyonium tuberosum. J. Bauh. hist. III p. 817. In the "Historia Plantarum universalis" of Joh. Bauhin and Joh. Henr. Cherler dated 1651 there is in $v .3$ lib. 39 p. 817 a copy of the figure from Imperato, with the description Alcyonium tuberosum. This reference also must be assigned to the sponge.

(3) Ficus substantia inter Spongiam et Alcyonium medice. Marsil. hist. mar. p. 87 tab. 16 n. 79 . This reference is to the "Histoire physique de la Mer" by L. F. Marsilli dated 1725. The passage there reads exactly: "Figue de substance d'Eponge \& d'Alcion, nommée par Trionfetti, Alcyonium tuberosum, forma ficus Imperati." The coasts of Barbary are given as locality. This reference also, as may be seen from the figure, t. 16 , f. 79 , without doubt has to do with a sponge and Ficulina ficus is indicated. A copy of this figure is to be found also in Esper (1806).

(4) Alcyonium quintum antiquorum. Mercat. metall. arm. 6. c. 6 . p. 102. In his "Metallotheca Vaticana" dated 1717 Mercati describes, under the title "De quinto antiquorum alcyonio," a form which is also a sponge and must be regarded as a synonym of Ficulina ficus. The figure bears the legend "Alcyonium quintum."

(5) Pulmo marinus alter Rondeletii. Raj. syn. p. 31. n. 3. In the 3rd Edition of his "Synopsis methodica Stirpium Britannicarum" dated 1724, J. Ray puts forward the Pulmo marinus alter Rondel. as a synonym for Bursa marina.-Rondelet's species cannot be determined. The Bursa marina is on the other hand an Alga. The reference from Ray does not therefore come into consideration either in connection with the sponge or the ascidian. In the first edition of this work dated 1690, which Lendenfeld (1896) quotes, I do not find "Pulmo marinus" mentioned.

Some references, also relating to the sponge, which are lacking in the list of synonyms in Pallas, should now be added. In the first place a reference which is to be found in Bonanni, in his "Musæum Kircherianum" dating from 1709 and reads: "Aliud Alcionum ex Mari Adriatico acceptum visitur, quod Tuberosum vocavit Imperatus." Further the "Alcionio minore in figura di fico frutto" mentioned and figured by Ginanni (1757) in his "Opere postume," v. 1 p. 41 t. 47 f. 98. Finally the "Alcyonium tuberosum Ficus forma Imp." mentioned by Battarra in a new edition of the "Museum Kircherianum" dated 1773 , p. 179 (note). 
The next author after Pallas is Linnæus. In the 12th and also in the 13th Edition of the "Systema Naturæ" he records an Alcyonium (Alcionium) Ficus with the same synonymy as Pallas. This literature reference is thus also a partial synonym of both species.

The Dutch translation of Pallas' Elench. Zooph, by Boddært (1768), Houttuyn's edition (1772) of Linnæus' Syst. Nat. ed. 12, St. Müller's German edition (1775) of the same work, and an extract from Müller's edition by Höslin (1782) give nothing new.

The Alcyonium Ficus, which Berken hout mentions in the "Outlines of the natural History of Great Britain and Ireland" dated 1769, refers to Ellis' form, and is therefore exclusively a synonym of the Ascidian. The species appears again later in both editions of the "Synopsis of the natural History of Great Britain and Ireland" by the same author dated 1789 and 1795 , which constitute the 2nd and 3rd editions of the "Outlines."

To Ellis and Solander belongs the credit of having pointed out for the first time in their "History of Zoophytes," in the year 1786, the specific difference between the sponge and the ascidian. The ascidian originally called "Sea-Fig" by Ellis received the name "Alcyonium Pulmonaria," without however the authors having recognised its ascidian nature. For the determination of the correct specific name this reference is however of decisive significance, for here the Alcyonium ficus was for the first time divided into two species, of which the one (the ascidian) received the new specific name " pulmonaria," whilst the other (the sponge) retained the original specific name "ficus." Ellis and Solander refer to the mistaken union of the two species in the following words :- "This name of Sea-Fig [of Ellis] has occasioned a mistake in some late authors, who have confounded it with the SeaFig of Count Marsigli, which is a true sponge."

The following years yield a series of literature references, which either cannot be accurately determined or in which both species are again confounded. To the latter class belong the Alcyonium Ficus in the translation of Pallas' Elench. Zooph. by Wilkens and Herbst (1787), the Alcyonium Ficus which Meuschen records in the "M useum Geversianum"(1789), the Alcyonium ficus of Bruguière in the "Encyclopédie méthodique" (1787), the Alcyonium Ficus in Gmelin's edition of the "Systema naturæ" (1791) and in the English edition of this work by Turton (1806).

Not decisively to be indicated are the Alcyonium Ficus, which Olivi (1792) recorded from the Gulf of Venice, and the Alcyonium ficus, which Cuvier (1798) mentions in his "Tableau élémentaire" without literature reference or locality. The first of these cannot, owing 
to the locality where it was found, be referred to the ascidian. Whether both references belong to the sponge must remain undetermined.

To the sponge must be assigned the Alcyonium Ficus, which Poiret records in his "Voyage en Barbarie" of the year 1789. To the ascidian on the other hand the Alcyonium ficus of Bose mentioned in his "Histoire naturelle des Vers" (1802). In the second edition of that work of the year 1827 Bosc has however again combined the two species, since he here, in addition to the reference to Ellis, gives also as a synonym the A. Ficus of Lamouroux (1816), which refers to the sponge.

The Alcyonium ficus, which Borowski and Herbst figure in their "Naturgeschichte des Thierreichs" (1787) is a copy of Ellis' figure. In the text however no literature is referred to and the locality is given as the Mediterranean. In the synonymy of the ascidian therefore only the reference to the figure can be accepted.

Esper then again separated the two species in his large work on the "Pflanzenthiere." What he deseribes as Alcyonium Ficus is the sponge, whilst the ascidian is left without a binomial designation. In Esper there is also to be found a careful summary of the literature.

In his "British Fauna" of the year 1807 Turton records an Alcyonium Ficas [sic!], which must be ranked as the ascidian.

Then in the years 1815 and 1816 there follow the important works of Lamarck and Lamouroux, which treat of both species under binomial names. Nevertheless the true nature of the two species was still not recognised, and they were both left in the genus Alcyonium. For the sponge Lamarck introduced the new but superfluous name Alcyonium ficiforme. The Mediterranean was given as locality. For the ascidian on the other hand the name Alcyonium pulmonaria, originating from Ellis and Solander, was applied, and as localities the Atlantic Ocean and the Channel were given.

Lamouroux in his "Histoire des Polypiers coralligènes flexibles," dated 1816, also retains for the ascidian the name Alcyonium Pulmonaria, whilst for the sponge he uses the correct nomenclature, that is to say the specific name Alcyonium Frous.

By the important work of Savigny of the year 1816, it was conclusively proved that the colony-building Ascidians, which until then had been placed with the alcyonians and polyps, ought to be united to the simple ascidians. Thus Ellis' form took its place definitely amongst the ascidians, and Savigny indeed placed it in the new genus Aplidium, which he then founded. He only made a mistake in the choice of the specific name, since he called the species Aplidium ficus, instead of employing the name pulmonaria given to it by Ellis and 
Solander. The consequence of this mistake is that the specific name ficus has been retained until the present day in the ascidian literature, but has also been used at the same time by writers on sponges. I have already shown that the name ficus cannot be maintained for an ascidian, but must fall to the sponge. Savigny does not discuss the sponge further.

Another new name for the ascidian was introduced in the same year by Lamarck in his "Histoire naturelle des Animaux sans Vertèbres." Although he recognises the genus Aplidium founded by Savigny, he calls the species Aplidium sublobatum. Why he should introduce this new specific name, although he had in the year 1815 designated the species Alcyonium pulmonaria, is not very easy to see. Moreover he retains the sponge in the genus Alcyonium and keeps the name A. ficiforme.

The year 1816 therefore fixes the time from whence onwards the two species finally remain separate. Ellis' form is recognised as ascidian, whilst it is not until many years later that Alcyonium ficus is regarded as a sponge and placed first in the genus Suberites, later in Halichondria, finally in the genus Ficulina, which was established specially for this species. With this definite separation of the two species only the further history of the ascidian will continue to interest us here, but before proceeding, I should like to consider briefly Lendenfeld's paper on the "Clavulina der Adria" published in 1896. A summary of the literature on Ficulina ficus is given in this paper, which contains some errors in the old references previous to the year 1816, which may be here corrected. In the first place there is placed amongst the synonyms the Alcyonium pulmonis instar lobatum of Ellis. I can only suppose that Lendenfeld had no personal acquaintance with Ellis' work, or he would never have regarded the figure which Ellis gives as that of a sponge. As the earliest literature reference Baubin and Cherler, 1651 (not 1650 !) are quoted. This is not correct. Bauhin and Cherler indeed are based on Imperato and even give an extract from the work of the latter. I have already referred to the reference to Ray (1690), which also contains an error. A further mistake, finally, is that Lendenfeld ascribes the authorship of the name ficus to Linnæus instead of to Pallas.

I now proceed with the history of the ascidian. After Savigny's species had been placed, in the year 1816, in his genus Aplidium, as Aplidium ficus, the specific name ficus was prevalent for 30 years. Only in quite isolated instances the synonymous specific name sublobatum, derived from Lamarck, appeared along with it. On the other hand the generic name was changed repeatedly. This is explained by the fact 
that Sa vigny's genera were to a large extent again united by later authors. Thus our species appears sometimes as Polyclinum ficus, sometimes as Synoicum ficus, sometimes as Pulmonellum ficus, in isolated instances indeed still as Alcyonium ficus. It would take us too far to discuss this literature in detail. I must content myself with pointing out here only the most important facts in the history of the species. It will be best first of all to follow, up to recent times, the specific name ficus, which predominated in the older literature till about the year 1850 .

The older works belonging to the first half of the last century, in which the species is referred to, are without exception in the nature of compilations, and bring nothing new to our knowledge of the species. To this category belong the references by Cuvier (1817), Goldfuss (1820), Fleming (1820, 22), Schinz (1822), Fleming (1824), Lamouroux (1824), Blainville (1824, 25, 27), Fleming (1828), Stark (1828), Rang (1829), Blainville (1829, 30), Cuvier (1830), Voigt (1834), Blainville (1834), Oken (1835), Cuvier (1836), Blainville (1837), Fleming (1837), Dujardin (1837, 40), Gervais (1840), Comte (1840) (under the name Distoma variolatus this author gives a copy of Ellis' figure), Reichen bach (1842), Deshayes (1842), Poeppig (1848), Forbes and Hanley (1848) also do not know the species from their own observation, but quote from Ellis. From the second half of last century the following references, belonging to the same category should be mentioned: Wright (1855), Gosse (1856), H. and A. Adams (1858), M'Andrew (1861), Granger (1886), Herdman (1891), Lameere (1895), Maitland (1897), and finally also Hartmeyer (1909).

The following works contain some remarks on the species, in some cases only records of new localities :-

Alder and Hancock (1848) mention an Aplidium ficus from Cullercoats, but leave the identification uncertain. The record of locality had better therefore for the present remain doubtful, although it is not unlikely that the species occurs there.

Cocks (1850) records in his list of the Ascidians of Falmouth an Aplidium ficus. The identification cannot be tested. That the species occurs on the south coast of England I consider doubtful, until the contrary is proved. At any rate I have not found it amongst the extensive collection from Plymouth which I have examined. This locality therefore may for the present remain doubtful.

Gervais and P. J. Beneden (1859) give the North Sea as a locality. P. J. Beneden (1860) records the occurrence of Aplidium ficus in deep water on the Belgian coast in company with a second species which he calls Aplidium ficoides. Details of the anatomy 
are not given however, but it seems possible to decide with certainty from the external characters alone that it refers to our species. Aplidium ficoides is probably only a synonym. I have recently had in my hands many colonies which were also collected off the Belgian coast, so that the occurrence of the species there is certain.

Ansted and Latham also record Aplidium ficus in a list of the Ascidians of the Channel Islands. This statement cannot be tested. I have myself not seen any example of this species from the Channel Islands, although I have identified a great deal of ascidian material from that locality. It appears however by no means improbable that the species occurs there, probably in deeper water. I come to that conclusion because Giard (1873) also mentions a Polyclinum ficus from the neighbouring coast of Granville, which he identifies as Ellis' species. I do not doubt that this $P$. ficus of Giard is the same as our species. Giard thinks it probable that the species lives in deep water and is only occasionally thrown on the shore. That would also explain the fact that the species is mentioned neither by MilneEdwards nor by Lahille, and consequently we may conclude that it does not occur within the limits of the true littoral zone on the north coast of France.

Pelseneer (1892) mentions the species from Blankenberghe, where it is frequently taken by the fishermen; Bizet (1892) from the coast of Somme. It seems to me however questionable whether in the latter case our species is really concerned, possibly there is a confusion with Glossoforum sabulosum. Sharp (1911) mentions the species again from the Channel Islands (Cobo). The same remarks apply to this record as to that of Ansted and Latham. Finally in the posthumous work of Alder and Hancock (1912) published by Hopkinson a numerous collection of references to this species is to be found, in which however references which belong to the sponge are erroneously included. In other respects this work furnishes nothing new.

An Aplidium or Polyclinum ficus is also repeatedly recorded from the Mediterranean. Thus by Martens (1824), Grube (1864), Faber (1883), and Carus (1890); Targioni-Tozzetti (1880) mentions an Aplidium sublobatum. In all these cases there is a mistaken identification, since our species does not occur in the Mediterranean. Probably in most cases the form dealt with is Amaroucium pyramidale (Brug.) (Syn. A. conicum (Olivi)).

It is interesting to follow how in the course of years the specific name ficus disappears more and more from the literature. Up to the middle of the last century one misses it in hardly a single general 
work on ascidians. In the fifties and sixties also it is still somewhat frequently mentioned. After that the name becomes constantly less frequent and in the most recent times it has as good as completely disappeared from the literature. But although in the older literature the species was recorded so very frequently, no author has given us an anatomical description sufficient to enable us to place the species with certainty in the present system. For in order to recognise the form, as Giard does, as Polyclinum, the proof must first be forthcoming that it actually agrees with the genus Polyclinum in the arrangement of the intestinal loop, the most important generic character of that genus. For such a proof one seeks in vain in the whole literature of the species. The form has remained, one may rather say, problematical as regards its systematic position up to the present day. By the reexamination of typical, local specimens this question is now solved. The identity of the Alcyonium pulmonis instar lobatum of Ellis with the frequently mentioned Macroclinum pomum (Sars) of recent literature has been established.

The latter species was first described by Sars (1851) as Amaroucium pomum, and was placed later by Huitfeldt-Kaas (1896) in the genus Aplidiopsis founded by Lahille, together with a newly described species A. sarsii. Hartmeyer (1903) then recognised the near relationship of these two species to Macroclinum crater, described by Verrill (1871), from the Newfoundland Banks, which was the type of the new genus Macroclinum, Aplidiopsis sarsii was explained as a synonym of $M$. crater, whilst $A$. pomum was placed as an independent species in the genus Macroclinum. Bjerkan (1905) afterwards showed that $M$. crater and $M$. pomum were also synonyms, and that the species should bear the latter name. This name has been retained until the present day. Now the name pomum has to be replaced by the older name pulmonaria, so that the species must now be called Macroclinum pulmonaria (Ell. Sol.). Naturally the position of the species as type of the genus Macroclinum remains unaffected by this change of name.

In conclusion I add a list of the most important references to Ficulina ficus (Pall.) up to the year 1816, as well as of the whole literature on Macroclinem pulmonaria (Ell. Sol.) as far as it is known to me

\section{FICULINA FICUS (PALL.).}

1478 "Alcionii quinta species," Dioscorides, Materia medica, lib. 5 cap. 90. 1599 "Alcyonio tuberoso in forma di fico, fiutto: Alcyonio quinto di Dioscoride," Imperato, Stor. nat., p. $734 \mathrm{f}$.

1651 "Alcyonium tuberosum," Bauhin \& Cherler, Hist. Plant. univ., v. 3 lib. 39 p. $817 \mathrm{f}$. 
1709 "Alcionum . . . , quod Tuberosum vocavit Imperatus," Bonanni, Mus. Kircher., p. 267.

1717 "Alcyonium quintum" (quintum antiquorum alcyonium), Mercati, Metallotheca Vatic., p. $102 \mathrm{f}$.

1725 "Figue de substance d'Eponge \& d'Alcion, nommée par Trionfetti, Alcyonium tuberosum, forma ficus Imperati," Marsilli, Hist. phys. Mer, p. 87 t. 16 f. 79.

1757 "Alcionio minore in figura di fico frutto," Ginanni, Oper. post., v. 1 p. 41 t. 47 f. 98 .

1766 Alcyonium Ficus (part.), Pallas, Elench. Zooph., p. 356.

1767 Alcyonium Ficus (part.), Linné, Syst. Nat., ed. 12 v. 1 II p. 1295.

1767 Alcionium Ficus (part.), Linné, Syst. Nat., ed. 13 v. 1 II p. 1295.

1773 "Alcyonium tuberosum Ficus forma Imp.," Battarra in: Bonanni, Mus. Kircher., p. 178, 179 nota.

1786 "Sea-Fiq," Ellis \& Solander, Zooph., p. 206 t. 59 f. 4.

1789 Alcyonium Ficus, Poiret, Voy. Barbarie, v. 2 p. 57.

1791 Alcyonium Ficus (part.), Gmelin, Syst. Nat., v. 1 VI p. 3813.

?1792 Alcyonium Ficus, Olivi, Zool. Adriat., p. 240.

? 1798 Alcyonium ficus, G. Cuvier, Tabl. élém., p. 682.

1806 Alcyonium ficus, Esper, Pflanzenth., pars 3 fasc. 2 (14) p. 63 t. Alc. 20 f. $1-4$.

1815 Alcyonium ficiforme, Lamarck in: Mém. Mus. Paris, v. 1 p. 75.

1816 Alcyonium ficiforme, Lamarck, Hist. An. s. Vert., v. 2 p. 394.

1816 Alcyonium Ficus, Lamouroux, Hist. Polyp., p. 348.

1896 Ficulina ficus, Lendenfeld in: N. Acta Ac. Leop., v. 69 nr. 1 p. 94.

\section{MACROCLINUM PULMONARIA (ElL. Sol.).}

1755 Alcyonium pulmonis instar lobatum, Ellis, Corallin., p. 82 t. 17 f. b, B, C, D. non bin.

1756 Alcyonium pulmonis instar lobatum, Tak, Ellis Koraal-Gewass., p. 89 t. 17 f. b, B, C, D. non bin. [Dutch translation of Ellis, Corallin.] 1756 Alcyonium pulmonis instar lobatum, Allamand, Ellis, Corallin., p. 97

t. 17 f. b, B, C, D. non bin. [French translation of Ellis, Corallin.]

1766 Alcyonium Ficus (part.), Pallas, Elench. Zooph., p. 356.

1767 Alcyonium Ficus (part.), Linné, Syst. Nat., ed. 12 v. 1 II p. 1295.

1767 Alcionium Ficus (part.), Linné, Syst. Nat., ed, 13 v. 1 II p. 1295.

1767 Alcyonium pulmomis instar lobatum, Krüniz, Ellis, Corall-Art., p. 89

t. $17 \mathrm{f}, \mathrm{b}, \mathrm{B}, \mathrm{C}, \mathrm{D}$. non bin. [German translation of Ellis, Corallin.]

1768 Alcyonium ficus (part.), Boddært, Plant-Dier., p. 442 t. 11 f. 3.

[Dutch translation of Pallas, Elench. Zooph.].

1769 Alcyonium Ficus, Berkenhout, Outl. Hist. Great Brit., v. 1. p. 210.

1772 Alcyonium Ficus (part.), Houttuyn, Natural. Hist., pars 1 v. 17 p. 398.

[Dutch translation of Linné, Syst. Nat., ed. 12.]

1775 Alcyonium ficus (part.), St. Miiller, Natursyst. Linné, $v$. 6 II p. 787.

[German translation of Linné, Syst. Nat., ed. 12.]

1782 Alcyonium ficus (part.), Höslin, Linné, Natur-Syst., v. 2 p. 608. 
1786 Alcyonium Pulmonaria, Ellis \& Solander, Zooph., p. 175.

1787 Alcyonium Ficus (part.), Meuschen, Mus Gevers., p. 532.

1787 Alcyonium Ficus (part.), Wilkens \& J. F. W. Herbst, Pallas Thierpfl., v. 2 p. 121 t. 18 f. 63 . [German translation of Pallas, Elench. Zooph.]

1787 Alcyonium ficus, J. F. W. Herbst in: Borowski \& J. F. W. Herbst, Naturg. Thierr., atl. $v .9$ t. 65 f. 1 a, b.

(non 1787 Alcyonium ficus, J. F. W. Herbst in: Borowski \& J. F. W. Herbst, Naturg. Thierr., v. 10 p. 77.)

1789 Alcyonium Ficus, Berkenhout, Synops. Hist. Great Brit., ed. 2 v. 1 p. 213.

1789 Alcyonium ficus (part.), Bruguière in: Enc. méth., Vers v. 1 p. 26.

1791 Alcyonium Ficus (part.), Gmelin, Syst. Nat., v. 1 VI p. 3813.

1795 Alcyonium Ficus, Berkenhout, Synops. Hist. Great Brit., ed. 3 v. 1 p. 213.

1802 Alcyonium ficus, Bosc, Hist. Vers, v. 3 p. 133.

1806 Alcyonium Ficus (part.), Turton, Syst. Nat. Gmelin, v. 4 p. 653. [English edition of Gmelin, Syst. Nat.]

1806 Alcyonium Ficus (part.), Esper, Pflanzenth., v. 3 fasc. 2 (14) t. Alc. 20 f. 5-8.

1807 Alcyonium Ficas (err.), Turton, Brit. Fauna, v. 1 p. 207.

1815 Alcyonium pulmonaria, Lamarck in: Mém. Mus. Paris, v. 1 p. 76.

1816 Alcyonium Pulmonaria, Lamouroux, Hist. Polyp., p. 342.

1816 Aplidium sublobatum, Lamarck, Hist. An. s. Vert., v. 3 p. 95.

1816 Aplidium ficus, Savigny, Mém. An. s. Vert., v. 2 p. 183.

1817 Polyclinum ficus, G. Cuvier, Règne an., v. 2 p. 501.

1817 Alcyonium ficus, Anonym in: Enc. Brit., ed. 5 v. 10 p. 358.

1820 Polyclinum ficus, Goldfuss, Handb. Zool., v. 1 p: 591.

1820 Alpidium (err.) ficus, J. Fleming in: Edinb. Enc., v. 14 p. 631.

1821 Aplidium ficus, Lamouroux, Expos. Polyp., p. 74.

1822 Aplidium (err.) ficus, J. Fleming, Phil. Zool., v. 2 p. 514.

1822 Polyclinum Ficus, Schinz, Thierr. Cuvier, v. 2 p. 781.

1824 Aplidium ficus, Lamouroux in: Enc. méth., Zooph. p. 75.

1824 Synoicum Fieus, Blainville in: Dict. Sci. nat., v. 32 p. 367.

1824 Alpidium (err.) ficus, J. Fleming in: Enc. Brit., ed. 4, 5, 6 suppl. v. 5 p. 583.

(non 1824 Polyclinum ficus, G. Märtens, Reise Venedig, v. 2 p. 480.)

1825 Synoicum Ficus, Blainville, Man. Malac., p. 587 t. 82 f. 6,6 a, 6 b.

1827 Synoicum ficus, Blainville in: Dict. Sci. nat., v. 51 p. 484.

1827 Alcyonium ficus (part.); Bosc, Hist. Vers, ed. 2 v. 3 p. 160.

1828 Alpidium (err.) ficus, J. Fleming, Hist. Brit. An., p. 470.

1828 Aplidium sublobatum, Stark, El. nat. Hist., v. 2 p. 121.

1829 Synoicum ficus, Rang, Man. Moll., p. 355.

1830 Pulmonellum ficus, Blainville in: Dict. Sci. nat., v. 60 p. 489.

[1816-1830] "Synoique sublobé" [Synoicum ficus], Blainville in: Dict.

Sci. nat., pl. Zool. Conchyl. t. 113 f. 6, 6 a.

1830 Polyclinum ficus, G. Cuvier, Règne an., ed. 2 v. 3 p. 169 : 
1834 Polyclinum Ficus, F. S. Voigt, Thierr. Cuvier, v. 3 p. 596.

1834 Pulmonellum ficus, Blainville, Man. Actin., p. 526.

1835 Alcyonium ficus, Oken, Allg. Naturg., v. 5 I p. 93.

1836 Polyclinum ficus, G. Cuvier, Règne an., ed. 3 v. 2 p. 105.

[1837] Pulmonella ficus, Blainville, Man. Actin., p. 683.

1837 Alpidium (err.) ficus, J. Fleming in: Enc. Brit., ed. 7 v. 15 p. 370 ; Moll. An., p. 213.

1837 Aplidium sublobatum, Dujardin in : Lamarck, Hist. An. s. Vert., ed. 3 v. 1 p. 570.

1840 Aplidium sublobatum, Dujardin in : Lamarck, Hist. An. s. Vert., ed. 2 v. 3 p. 489.

1840 Aplydium (err.) ficus, Gervais in: Dict. Sci. nat., suppl. v. 1 p. 410.

[1840] Distoma Variolatus (part.) + Synoicum Ficus, Comte, Règne an., t. 28 f.

1842 Polyclinum Ficus, Reichenbach, Conchil., p. 125.

[1842] Polyclinum ficus, Deshayes in: Cuvier, Règne an. [ed. 4], Moll. p. 245.

1848 Aplydium (err.) ficus, Poeppig, Naturg. Thierr, v. 4 p. 223 f. 3945 a, b.

1848 Aplidium ficus, Alder \& Hancock in: Tr. Tyneside Club, $v .1$ p. 203.

1848 Aplidium ficus, E. Forbes in: E. Forbes \& Hanley, Brit. Moll., v. 1 p. 11.

? 1850 Aptidium ficus, Cocks in : Rep. Cornwall Soc., 1849 p. 73.

1851 Amaroucium pomum, M. Sars in: Nyt. Mag. Naturv., v. 6 p. 155.

1855 Aplidium ficus, Wright in: Nat. Hist. Rev., v. 2 Proc. p. 70.

1856 Aplidium ficus, Gosse, Man. mar. Zool., v. 2 p. 32.

1858 Aplidium ficus + Amouroucium pomum, H. \& A. Adams, Gen. Moll. p. 600,601 .

1859 Amaroucium pomum, M. Sars in: Forh. Selsk. Christian., 1858 p. 66.

1859 Aplydium (err.) ficus, Gervais \& P. J. Beneden, Zool. méd., v. 2, p. 74 .

1860 Aplidium ficus, P. J. Beneden in: Bull. Ac. Belgique, ser. $2 v .9$ p. 154.

1861 Aplidium ficus, McAndrew in: Rep. Brit. Ass., v. 30 p. 222.

? 1862 Aplidium ficus, Ansted \& Latham, Chann. Isl., p. 219.

1863 Amaroecium (err.) pomum, Alder in: Ann. nat. Hist., ser. 3 v. 11 p. 170.

(non 1864 Aplidium ficus, Grube, Lussin, p. 58.)

1865 Polyclinum sp., Alder in: Nat. Hist. Tr. Northumb., v. 1 p. 11.

1871 Macroclinum crater, A. E. Verrill in: Amer. J. Sci., ser. $3 v$. 1 p. 293 f. $23-25$.

1872 Macroclinum crater, A. E. Verrill in: Amer. J. Sci., ser. $3 v .3$ p. 212.

1873 Polyclinum ficus, Giard in: Arch. Zool. expér., v. 2 p. 493.

1879 Macroclinum crater, A. E. Verrill, Check. L. mar. Invert., p. 27.

(non 1880 Aplidium sublobatum, Targioni-Tozzetti, Espos. Pesca Berlino, cat, ital. p. 137.) 
1882 Aplydium (err.) ficus, Pelseneer in: Ann. Soc. malac. Belgique, $v$. 17 p. 40.

(non 1883 Polyclinum ficus, G. L. Faber, Fish. Adriatic, p. 251.)

1886 Aplidium ficus, Granger in: Hist. nat. France, v. 7 p. 206.

(non 1890 Aplidium ficus, J. V. Carus, Prodr. F. Medit., v. 2 p. 483.)

1891 Polyclinum ficus, Herdman in: J. Linn. Soc. London, v. 23 p. 619.

1891 Amaroucium pomum, Herdman in: J. Linn. Soc. London, v. 23 p. 628.

1891 Macroclinum crater, Herdman in: J. Linn. Soc. London, v. 23 p. 628.

? 1892 Aplidium ficus, Bizet in: Mém. Soc. Nord France, v. 8 p. 389.

1893 Amaroucium pomum, Herdman in: Ann. nat. Hist., ser. 6 v. 12 p. 445 .

1895 Polyclinum ficus, Lameere, Man. Faune Belgique, p. 42 f. 5.

1896 Aplidiopsis pomum, Huitfeldt-Kaas in: Norske Nordhavs-Exp., $v .7$ ser. 23 I p. 13 t. 1 f. $8-10$.

1896 Aplidiopsis sarsii, Huitfeldt-Kaas in: Norske Nordhavs-Exp., $v .7$ ser. 23 I p. 14 t. 1 f. 11-13.

1897 Amaroucium pomum, Norman, Mus. Norman., cat. IX p. 6.

1897 Aplidium ficus, Maitland, Prodr. Faune Pays-Bas, p. 34.

1903 Macroclinum crater, Hartmeyer in: Fauna arctica, v. 3 p. 319 t. 6 f. 5 ; t. 13 f. 6,7 .

1903 Macroclinum pomum, Hartmeyer in: Faune aretica, v. 3 p. 322.

1905 Macroclinum pomum, Bjerkan in : Bergens Mus. Aarbog, 1905 nr. 5 p. 17.

1906 Macroclinum pomum, Hartme yer in: Wiss. Meeresunters, v. 8 p. 126.

1907 Macroclinum crater, Redikorzew in: Annuaire Mus. St.-Pétersb., v. 11 p. $148,153$.

1908 Macroclinum pomum, Bjerkan in : Tromsö Mus. Aarsh., nr. 25 p. 88.

1909 Polyclinum ficus, Hartmeyer in: Bronn's Kl. Ordn., v. 3 suppl. p. 1461, 1481.

1909 Macroclinum pomum, Hartmeyer in: Bronn's Kl. Ordn., v. 3 suppl. p. 1464.

1909 Aplidium sublobatum, Hartmeyer in: Bronn's Kl. Ordn., v. 3 suppl. p. 1469.

1910 Macroclinum pomum, Hartmeyer in: Bronn's Kl. Ordn., v. 3 suppl. p. 1584 nota.

1910 Macroclinum pomum, Van Name in: P. Boston Soc., v. 34 p. 396 f. 21 t. 38 f. 8 .

1910 Macroclinum pomum, Redikorzew in: Trav. Soc. St.-Pétersb., v. 41 fasc. 2 p. 156 f. 42 .

1911 Macroctinum pomum, Redikorzew \& Hartmeyer in: Derjugin in : Trav. Soc. St.-Pétersb., v. 42 fasc. 1 nr. 1-2 p. 24.

1911 Polyclinum ficus, W. E. Sharp in: Rep. Guernsey Soc., 1910 p. 207.

1912 Amaroucium pomum, Alder \& Hancock, Brit. Tun., v. 3 p. 16.

1912 Aplidium ficus, Alder \& Hancock, Brit. Tun., v. 3 p. 23, 101 f. 97-99.

1912 Macroctinum pomum, Hartmeyer in: Vid. Meddel., v. 63 p. 280. 


\section{DISTRIBUTION.}

England And Scotland: Moray Firth (Alder 1863)—? Cullercoats (Alder and Hancock 1848)-West Mersea-Sheerness (Berkenhout 1769) —Whitstable (Ellis 1755) —? Falmouth (Bream Bay; Helford River) (Cocks 1850).

English Channel: (Lamarck 1815)-(Granger 1886).

Channel Islands: Guernsey (Ansted and Latham 1862)-Cobo (Sharp 1911). North Coast of France: Granville (Giard 1873)-Somme (Bizet 1892).

Belgian Coast : (Beneden 1860)-Blankenberghe (Pelseneer 1882).

North SeA : (Gervais and Beneden 1859)-Heligoland (Hartmeyer 1906)Dogger Bank (Alder 1865; Hartmeyer 1906)—Great Fisher Bank (Hartmeyer 1906) - 56 $6^{\circ} 1^{\prime}$ N. $4^{\circ} 49^{\prime}$ E., 38 m.-S.W. Lindesnaes, $57^{\circ} 2^{\prime}$ N. $4^{\circ} 3^{\prime}$ E., 64 m. $-57^{\circ} 11^{\prime}$ N. $0^{\circ} 11^{\prime}$ E., 78 m. $-57^{\circ} 41^{\prime} \mathrm{N}$. $5^{\circ} 35^{\prime}$ E., $100 \mathrm{~m} .-57^{\circ} 20^{\prime}$ N. $8^{\circ} 2^{\prime}$ E., 57 m. (Bjerkan 1905). *

Scandinavia and Denmark: Baadsfjord (E.-Finmark), 65 m. (Bjerkan 1905) - Gjesver (Bjerkan 1908)-Havösund, $72 \mathrm{~m}$. (Sars 1851)-Tromsö, 54-72 m. (Hartmeyer 1903)-Tromsösund, 40-100 m. (Bjerkan 1908)-Ure, Lofoten, 36 m. (Sars 1851)—Vestfjord near Bodö, 105$160 \mathrm{~m}$.-Trondhjemsfjord : Skarnsund, $150-200 \mathrm{~m}$. ; off Tautra, ca. $200 \mathrm{~m}$. ; off Rödberg, ca. 300 m. (Hartmeyer 1912); Rödberg (Herdman 1893)-Hessefjord, near Aalesund, $90 \mathrm{~m}$. (Bjerkan 1905) - Bohuslän - Beian - Christiansund (Huitfeldt-Kaas 1896) Hellebaek (Mus. Berlin)*_Grosser Belt (Mus. Berlin). $\dagger$

Murman Coast : Kola Fjord (Redikorzew and Hartmeyer 1911).

Spitzbergen : Stor Fjord, $77^{\circ} 8^{\prime}$ N. $20^{\circ}$ E., 155 m. (Redikorzew 1907).

FARÖE IsLANDS: North point of Nolsö, ca. $180 \mathrm{~m}$. (Hartmeyer 1912)-East of Faröes, $62^{\circ} 16^{\prime}$ N. $6^{\circ} 6^{\prime}$ W., 110 m. (Bjerkan 1905).

ICELAND : S.E. coast of Iceland, $64^{\circ} 17^{\prime}$ N. $14^{\circ} 44^{\prime}$ W., 75 m. (Bjerkan 1905). Greenland : S. of Cape Farewell (Hartmeyer 1910).

North East America: Newfoundland (Verrill 1871; Hartmeyer 1903; Van Name 1912)-Virgin Rock, $72 \mathrm{~m}$. (Van Name 1912).

Macroclinum pulmonaria is a decided sub-arctic species, which is distributed right across the North Atlantic from the east coast of North America to the Murman coast. On the American side it has only been found in Newfoundland. In the eastern part of the North Atlantic its most southerly locality is the north coast of France (Granville) and the Channel. It has not yet however certainly been proved to occur on the south coast of England, nor has it been found in the Irish Sea, on the Irish coasts, nor on the west coast of Scotland. On the other hand it is known from various points on the east coasts of

* Also collected at many other places in the North Sea during the quarterly cruises of the Poseidon and of the Heligoland fishery research vessels during the years 1902-5.

+ The Berlin Museum possesses in each case one small colony of this species from Hellebaek, Gundel leg., and from the Greater Belt, collected during the Pommerania expedition. Both localities are new. 
Scotland and England. From the Channel it extends along the Belgian coast and through the whole North Sea, where it appears to be very abundant everywhere, enters Danish waters (Greater Belt), and then follows the whole west coast of Sandinavia by Lofoten and Finmark to the Murman coast. Here its most easterly locality is the Kola Fjord. Towards the north it spreads through the Faröe Islands and Iceland to the neighbourhood of Cape Farewell on the one side and the Stor Fjord (Spitzbergen) on the other. Only at these two points does it go within the Arctic Circle, and it seems always to remain in the neighbourhood of the warmer currents. The whole area of distribution extends therefore from west to east from $48^{\circ} \mathrm{W}$. to $34^{\circ} \mathrm{E}$, from south to north from $48^{\circ} 50^{\prime} \mathrm{N}$. to $77^{\circ} 8^{\prime} \mathrm{N}$, , or through 82 degrees of longitude and 29 degrees of latitude.

The species generally prefers deeper water. The vertical distribution lies, as far as the records show, between 38 and 300 metres. A decided littoral form the species is certainly not. In the Channel it appears to occur only in deeper water, and is absent from the coastal zone. In many places it is clearly extraordinarily abundant, as for example in the North Sea, especially in the neighbourhood of the Dogger Bank and the Great Fisher Bank. The species appears to live chiefly on sandy ground.

\section{BIBLIOGRAPHY.}

Adams, H. \& Adams, A., The Genera of recent Mollusca ; arranged according to their Organization. v. 1, 2; atl. London. 1858(1853-58).

Alder, J., Observations on the British Tunicata, with Descriptions of several new Species. In: Ann. Nat. Hist., ser. 3 v. 11 p. $153-173$ t. 7. London. 1863.

Coasts of Northumberland and Durham, 1862-4. In: Nat. Hist. Tr. Northumberland, $v .1$ p. 511. London, Newcastle-on-Tyne. 1865 (1867).

Alder, J. \& Hancock, A., Tunicata. In: Alder, J., A Catalogue of the Mollusca of Northumberland and Durham. In: Tr. Tyneside Club, v. 1 p. 97-209. Newcastle-upon-Tyne, London. 1848 (1850).

- - The British Tunicata. An unfinished monograph by the late Joshua Alder and the late Albany Hancock. Edited by John Hopkinson. v. 1-3. London. 1905, 07, 12 .

Allamand, J. N. S., Essai sur l'histoire naturelle des Corallines. . . . Par Jean Ellis. Traduit de l'Anglais. La Haye. 1756.

Anonym., Encyclopædia Britannica. ed. 5, v. 1-20. Edinburgh. 1817.

Ansted, D. T. \& Latham, R. G., The Channel Islands. London. 1862.

Bauhin, Joh. \& Cherler, Joh. Henr., Historia Plantarum universalis. v. 1-3. Ebroduni. 1651. 
Beneden, P. J., Un nouveau genre de Crustacé lernéen. In: Bull. Ac. Belgique, ser. 2 v. 9 p. 151-160. Bruxelles. 1860.

Berkenhout, J., Outlines of the natural History of Great Britain and Ireland. $v$. 1. Comprehending the Animal Kingdom. London. 1769.

- - Synopsis of the natural History of Great Britain and Ireland. Ed. 2 (of the Outlines) $v$. 1. London. 1789; ed. 3 (of the Outlines) v. 1. London. 1795.

Bizet, E., Catalogue des Mollusques observés à l'état vivant dans le département de la Somme. In: Mém. Soc. Nord France, v. 8 p. 262-405. Amiens. 1892.

Bjerkan, P., Ascidien von dem norwegischen Fischereidampfer "Michael Sars" in den Jahren 1900-1904 gesammelt. In: Bergens Mus. Aarbog, 1905 nr. 5 p. 1-30 t. 1-3. Bergen. 1905.

—- Die Ascidien des nördlichen Norwegens. In: Tromsö Mus. Aarsh., nr. 25 p. 49-118, 1 t. Tromsö. 1908.

Blainville, H., Ascidiens. In : Dict. Sci. nat., Planches. Zool.: Conchyl. et Malacol., t. 113. Paris [1816-30].

_-, Mollusques, Mollusca. In: Dict. Sci. nat., v. 32 p. 1-392. Paris. 1824.

—- Manuel de Malacologie et de Conchyliologie . . cum atl. Paris. 1825; 27.

- - Synoique, Synoicum. In: Dict. Sci. nat., v. 51 p. 483-86. Paris. 1827.

_-, Manuel d'Actinologie ou de Zoophytologie . . . cum atl. Paris. 1834; 37.

- Z, Zoophytes, Zoophyta. In: Dict. Sci. nat., v. 60 p. 1-546. Paris. 1860.

Boddaert, P., Lyst der Plant-Dieren. . . . In het Latyn beschreeven door P. S. Pallas. Vertaald . . . door P. Boddaert. Te Utrecht. 1768.

Bonanni, Ph., Musaeum Kircherianum sive Musaeum a P. Athanasio Kirchero . . oblatum a P. Philippo Bonanni. Romae. 1709.

- - Rerum naturalium historia nempe quadrupedum . . . existentium in Museo Kircheriano edita jam a P. Philippo Bonannio nunc vero nova methoda distributa . . . a Johanne Antonio Batarra Ariminensi. Pars prima. Romae. 1773.

Borowski, G. H. \& Herbst, J. F. W., Gemeinnützige Naturgeschichte des Thierreichs ...v. 1-10; atl. $v$. 1-10. Berlin \& Stralsund. 1780-89; 1780-87.

Bosc, L. A. G., Histoire naturelle des Vers, contenant leur Description et leurs Mœurs. v. 1-3. Paris, X [1806]; ed. $2 v .1-3$. Paris. 1827.

Bruguière, J. G., Encyclopédie méthodique, ou par Ordre de Matières ; . . . Histoire naturelle des Vers. $v .1$. Paris. 1789, 92.

Carus, J. V., Prodromus Faunæ Mediterraneæ sive Descriptio Animalium Maris Mediterranei Incolarum . . . v. 1, 2. Stuttgart. 1885 (1884, 85), 89-93 (1889, 90, 93).

Cocks, W. P., Contributions to the Fauna of Falmouth. In: Rep. Cornwall Soc., 1849 p. 38-102. London, Falmouth. 1850.

Comte, A.; Règne animal de Cuvier disposé en Tableaux méthodiques. t. 28. Acéphales sans-coquilles. Paris. [1840.]

Cuvier, G., Tableau élémentaire de l'Histoire naturelle des Animaux. Paris. VI [1789 I]. 
Cuvier, G., Le Règne animal distribué d'après son Organisation. . . . v. 1-4. Paris. 1817 ; ed. 2 v. 1-5. Paris. 1829-30; ed. 3 v. 1-3. Bruxelles. 1836 ; [ed. 4]; par une Réunion de Disciples de Cuvier. $11 v$. $\& 10$ atl. Paris. 1836-49.

Deshayes, G. P., Les Mollusques. In: Cuvier, Règne an. [ed. 4]. Paris. [1842.]

Dioscorides, Materia medica. 1478.

Dujardin, F., Les Tuniciers (Tunicata). In: Lamarck, Hist. An. s. Vert., ed. 3 v. 1 p. 564-88. Bruxelles. 1837.

--, Les Tuniciens (Tunicata). In: Lamarck, Hist. An. s. Vert., ed. 2 v. 3 p. 473-541. Paris. 1840.

Ellis, J., An Essay towards a natural History of the Corallines and other Marine Productions of the like Kind, commonly found on the Coast of Great Britain and Ireland. London. 1755.

Ellis, J. \& Solander, D., The natural History of many curious and uncommon Zoophytes, collected from various Parts of the Globe. London. 1786.

Esper, E. J. Chr., Die Pflanzenthiere in Abbildungen nach der Natur ... v. 1-3; atl. Nürnberg. 1788-90, 91-99, 1805-30.

Faber, G. L., The Fisheries of the Adriatic and the Fish thereof. London. 1883.

Fleming, J., Mollusca. In : Edinb. Enc., v. 14 p. 598-635. Edinburgh. 1820.

—, The Philosophy of Zoology. . . . v. 1, 2. Edinburgh. 1822.

- , Mollusca. In : Enc. Brit., ed. 4, 5, 6 suppl. v. 5 p. 566-84. Edinburgh. 1824 .

—_, A History of British Animals. . . . Edinburgh. 1828.

_-, Molluscous Animals, including Shell Fish. . . . Edinburgh. 1837.

-_, Mollusca. In: Enc. Brit., ed. 7 v. 15 p. 324-78 t. 1-7. Edinburgh. 1837.

Forbes, E. \& Hanley, S., A History of British Mollusea and their Shells. v. 1-4. London. 1848(47)-52.

Gervais, P., Ascidies, Ascidia. In: Dict. Sci. nat., suppl. v. 1 p. 400-16. Paris. 1840.

Gervais, P. \& Beneden, P. J., Zoologie médicale. Exposé méthodique du Règne animal. . . . v. 1, 2. Paris, Londres, New-York. 1859.

Giard, A., Contributions à l'Histoire naturelle des Synascidies. In : Arch.

Zool. expér., v. 2 p. 481-514 t. 19. Paris. 1873.

Ginanni, G., Opere postume. v. 1, 2. Venezia. 1757.

Gmelin, J. F., Caroli a Linné Systema Naturæ ... ed. 13. Cura Jo. Frid. Gmelin. $\quad v$. 1 I-VII. Lipsiæ. 1788-91.

Goldfuss, G. A., Handbuch der Zoologie. v. 1, 2. Nürnberg. 1820.

Gosse, P. H., A Manual of Marine Zoology for the British Isles. v. 1, 2. London. 1855, 56.

Granger, A., Mollusques (Bivalves) Tuniciers, Bryozoaires. In : Hist. nat. France, v. 7. Paris. 1886. 
Grube, A. E., Die Insel Lussin und ihre Meeresfauna. Breslau. 1864.

Hartmeyer, R., Die Ascidien der Arktis. In : Fauna arctica, v. 3 p. 94-412 f. 1-52 t. 4-14. Iena. 1903.

- Die Ascidien der Olga-Expedition. In: Wiss. Meeresunters., v. 5 p. 85-95. Kiel \& Leipzig. 1904.

- Tunicata (Manteltiere). In : Bronn's Kl. Ordn., v. 3 suppl. p. 1281-1773 f. 1-43. Leipzig. 1909-11.

—, Ascidien aus dem Skagerrak, dem Trondhjemsfjord und von den Fär Öer. In: Vid. Meddel., v. 63 p. 261-286 f. 1-3. Kopenhagen. 1912.

Herdman, W. A., A revised classification of the Tunicata . . . In: J. Linn. Soc. London, v. 23 p. 557-652. London. 1891.

—, Tunicata. In : Norman, A. M., A Month on the Trondhjemfjord. In : Ann. nat. Hist., ser. 6 v. 12 p. 443-46. London. 1893.

Höslin, P., Carl von Linné Lehr-Buch über das Natur-System so weit es das Thierreich angehet. In einem vollständigen Auszuge der Müllerischen Ausgabe., v. 1, 2. Nürnberg. 1781, 82.

Houttuyn, M., Natuurlyke Historie of uitvoerige Beschryving der Dieren, Planten en Mineraalen, volgens het Samenstel van den Heer Linnæus. 3 Deelen. Amsterdam. 1761-85. 1 Deel. Dieren. 18 Stuck. Amsterdam. 1761-73.

Huitfeldt-Kaas, H., Synascidiæ. In: Norske Nordhavs-Exp., v. 7 ser. $23 \mathrm{I}$ p. 1-27 t. 1, 2. Christiania. 1896.

Imperato, F., Historia naturale. Napoli. 1599.

Krüniz, J. G., Herrn Johann Ellis, Versuch einer Natur-Geschichte der Corall-Arten. . . . Nürnberg. 1767.

Lamarck, J. B., Suite des Polypiers empatés. In: Mém. Mus. Paris, v. 1 p. 69-80. Paris. 1815.

- - Histoire naturelle des Animaux sans Vertèbres, . . . v. 1-5, 6 I \& II, 7. Paris. 1815-22 ; ed. 2 v. 1-11. Paris. 1835-45; ed. $3 v .1-3$. Bruxelles. 1837-39.

Lameere, A., Manuel de la Faune de Belgique. v. 1-3. Bruxelles. 18951907.

Lamouroux, J., Histoire des Polypiers coralligènes flexibles, vulgairement nommés Zoophytes. Caen. 1816.

—, Exposition méthodique des Genres de l'Ordre des Polypiers. . . . Paris. 1821.

- - Encylopédie méthodique, ou par Ordre de Matières. . . . Histoire naturelle des Zoophytes. . . . Paris. 1824 [1824, X 1827].

Lendenfeld, R., Die Clavulina der Adria. In: N. Acta Ac. Leop., v. 69 ser. 1 p. 1-251 t. 1-12. Halle. 1896.

Linné, C., Systema Naturæ . . . ed. 12. v. 1 I, II. Holmiæ. 1766, 67.

—_, Systema Naturæ ... ed. 13, ad ed. 12 reformatam Holmiensem. v. 1 I, II. Vindobonæ. 1767.

McAndrew, R., List of the British Marine Invertebrate Fauna. In: Rep. Brit. Ass., v. 30 p. 217-36. London. 1861. 
Maitland, R. T., Prodrome de la Faune des Pays-Bas et de la Belgique Flamande. . . . Leide. 1897.

Marsilli, L. F., Histoire physique de la Mer. Ouvrage enrichi de figures dessinées d'après le Naturel. Amsterdam. 1725.

Martens, G., Reise nach Venedig. v. 1, 2. Ulm. 1824.

Mercati, M., Metallotheca Vaticana. Romæ. 1717.

Meuschen, F. C., Museum Geversianum sive Index Rerum naturalium. . . . Rotterdami. 1787. [Scripsit F. C. Meuschen.]

Müller, St., Des Carl Linné vollständiges Natursystem nach der zwölften lateinischen Ausgabe. . . . v. 1-6, suppl. \& ind. Nürnberg. 1773-89. Norman, A. M., Tunicata. In: Mus. Norman., cat. IX. Durham. 1897.

Oken, L., Allgemeine Naturgeschichte für alle Stände. Thierreich. v. 1-4; ind. Stuttgart. 1833-42.

Olivi, G., Zoologia Adriatica Ossia. Bassano. 1792.

Pallas, P. S., Elenchus Zoophytorum sistens Generum Adumbrationes generaliores et Specierum cognitarum succinctas Descriptiones cum selectis Auctorum Synonymis. Hagæ-Comitum. 1766.

Pelseneer, P., Etudes sur la Faune littorale de la Belgique. Mollusques \& autres Animaux inférieurs recueillis sur la Côte Belge en 1882. In: Ann. Soc. malac. Belgique, v. 17 (ser. 3 v. 2) p. 31. Bruxelles. 1892.

Poeppig, E., Illustrierte Naturgeschichte des Thierreichs. v. 1-4. Leipzig. $1847-48$.

Poiret, Voyage en Barbarie, ou Lettres écrites de l'ancienne Numidie pendant les années $1785 \& 1786$, sur la Religion . . . ; avec un Essai sur l'Histoire Naturelle de ce pays, $v .1,2$. Paris. $1789,89$.

Raius (Ray), J., Synopsis methodica Stirpium Britannicarum: Tum Indigenis, tum in Agris cultis Locis suis dispositis; Additis Generum Characteristicis, Specierum Descriptionibus \& Virium Epitome, ed. 3. Londini. 1724.

Rang, S., Manuel de l'Histoire naturelle des Mollusques et de leurs Coquilles. .. Paris. 1829.

Redikorzew, W., Ein Beitrag sur Ascidienfauna der Arctis. In: Annuaire Mus. St.-Pétersb., v. 11 p. 126-154. St.-Pétersbourg. 1907.

- - Die Ascidien der arktischen Meere. In: Trav. Soc. St.-Pétersb., v. 41 fasc. 2 p. $87-175$ f. 1-50. Juriew. 1910.

—_ \& Hartmeyer, R., Tunicata. In : Derjugin, K.M., Zur Kenntnis der Fauna des Kola-Fjords. II.-III. In: Trav. Soc. St.-Pétersb., v. 42 fase. 1 p. $24 . \quad$ St.-Pétersbourg. 1911.

Reichenbach, A. B., Die Land-, Siisswasser-und See-Conchilien. . . . Leipzig. 1842.

Rondelet, G., Universæ aquatilium Historiæ pars altera, cum veris ipsorum Imaginibus. Lugduni. 1555.

Sars, M., Beretning om en i Sommeren 1849 foretagen zoologisk Reise i Lofoten og Finmarken. In: Nyt Mag. Naturv., v. 6 p. 121-211. Christiania. 1851. 
Savigny, J. C., Mémoires sur les Animaux sans Vertèbres. v. 2. Paris. 1816.

Schinz, H. R., Das Thierreich ... von Cuvier. Aus dem Französischen ... uibersetzt ... von H. R. Schinz, v. 1-4. Stuttgart \& Tübingen. 1821-25.

Sharp, E. W., The Ascidians of Guernsey. In : Rep. Guernsey Soc., 1911 p. 199-209. Guernsey. 1911.

Stark, J., Elements of natural History. . . . v. 1, 2. Edinburgh \& London. 1828.

Tak, J., Natuurlyke Historie van de Koraal-Gewassen. . . . Door Jan Ellis. Uit het Engels vertaald door Ian Tak. In's Gravenhage. 1756 .

Targioni Tozzetti, A., Crostacei, Insetti, Molluschi ed altri animali italiani interessanti la pesca. . . . In: Espos. internat. Pesca Berlino. 1880. Sez. Ital. Catal. Firenze. 1880.

Turton, W., A general System of Nature. . . By Charles Linné: Translated from Gmelin ....v. 1-7. London. 1806.

- - The British Fauna, containing a Compendium of the Zoology of the British Islands. . . . v. 1. Swansea. 1807.

Van Name, W. G., Compound Ascidians of the Coasts of New England and neighboring British Provinces. In: P. Boston Soc., v. 34 p. 339 424 f. 1-25 t. 34-39. Boston. 1910.

Verrill, A. E., Descriptions of some imperfectly known and new Ascidians from New England. In: Amer. I. Sci., ser. 3 v. 1 p. 54-58, 93100, 211-12, 288-94, 443-46 f. 1-26. New Haven. 1871.

--, Recent Additions to the Molluscan Fauna of New England and the adjacent waters, with notes on other species. In : Amer. J. Sci., ser. 3 v. 3 p. 209-14. New Haven. 1872.

- - Preliminary Check-List of the marine Invertebrata of the Atlantic Coast, from Cape Cod to the Gulf of St. Lawrence. New Haven. 1879.

Voigt, F. S., Das Thierreich. . . . Von Cuvier. Nach der ed. 2 übersetzt . . von F. S. Voigt. v. 1-6. Leipzig. 1831-43.

Wickens, Chr. F. \& Herbst, J. F. W., P. S. Pallas, Charakteristik der Thierpflanzen, worin von den Gattungen derselben allgemeine Entwürfe und von denen dazugehörigen Arten kurze Beschreibungen gegeben werden. . . A Aus dem Lateinischen ibersetzt. . . . von Christian Friedrich Wickens, und. . . Johann Friedrich Wilhelm Herbst, $v .1,2$. Nürnberg. 1787.

Wright, E. P., On collecting and arranging the British Mollusca. In: Nat. Hist. Rev., v. 2 Proc. p. 65-85. London. 1855. 